\title{
ATRIAL FIBRILLATION: IMPORTANCE OF REAL WORLD DATA FROM REGIONAL REGISTRIES. A FOCUS ON THE BALKAN-AF REGISTRY
}

\section{ПРЕДСЪРДНО МЪЖДЕНЕ: ЗНАЧЕНИЕ НА ДАННИТЕ ЗА РЕАЛНИЯ СВЯТ ОТ РЕГИОНАЛНИТЕ РЕГИСТРИ. ФОКУС ВЪРХУ РЕГИСТЪР ВАLКАN-AF}

\author{
Monika Kozieł',2, Gregory Y. H. Lip ${ }^{1,2,3}$, Tatjana S. Potpara ${ }^{3,4}$ \\ ${ }^{1}$ Liverpool Centre for Cardiovascular Science, University of Liverpool and Liverpool Heart \& Chest Hospital, \\ Liverpool, United Kingdom \\ ${ }^{2}$ Department of Cardiology, Congenital Heart Diseases and Electrotherapy, Medical University of Silesia, \\ Silesian Centre for Heart Diseases, Zabrze, Poland \\ ${ }^{3}$ School of Medicine, Belgrade University, Belgrade, Serbia \\ ${ }^{4}$ Cardiology Clinic, Clinical Center of Serbia, Belgrade, Serbia
}

Адрес за кореспонденция: / Address for correspondence: Professor G. Y. H. Lip, e-mail: gregory.lip@liverpool.ac.uk

Реални световни регистри на пациенти с предсърдно мъждене (AF) предоставиха важни данни за съвременния подход към AF и за спазването на препоръките при пациенти от повечето европейски региони. Макар че перспективните рандомизирани клинични изпитвания дават златен доказателствен стандарт, трябва да признаем, че те имат специфрични критерии за включване/изключване и много групи пациенти могат да останат непредставени. Поради това има нужда от данни от реалния свят, целящи допълване и спазване на препоръките, особено при групи пациенти (напр. много възрастни и немощни, етнически малцинства, с краен стадий на бъбречна недостатъчност, от старчески домове, с когнитиви нарушения и т.н.), които са слабо представени или изключени от клинични проучвания.

Изследването BALKAN-AF е най-голямият проспективен, многоцентров (общо 49 центъра), набор от обсервационни данни за AF на Балканите - европейски регион, населяван от около $10 \%$ от европейското население, който е недостатъчно представен в много предшестващи клинични изпитвания или регистри [1]. В BALKAN-AF са събирани последователни данни за лица с електрокардиографски документирано невалвуларно AF от седем балкански страни (Албания, Босна и Херцеговина, България, Хърватия, Черна гора, Румъния и Сърбия) от кардиолог или специалист по вътрешни болести при липса на кардиолог. Изследването BALKAN-AF e създадено и проведено от Сръбската асоциация по предсърдно мъждене (от декември 2014 до февруари 2015 г.).
Real world registries of patients with atrial fibrillation (AF) have provided important evidence on contemporary AF management and adherence to guidelines in real-world patients across most of regions in Europe. While prospective randomized clinical trials are the 'gold standard' of evidence, we recognize that trials have specific inclusion/exclusion criteria and many groups of patients can be under-represented. Thus, real world evidence is needed to supplement and augment the evidence, especially for the under-represented patient groups (eg. the very elderly and frail, ethnic minorities, end stage renal failure, those in nursing homes, cognitive impairment, etc) that have been largely under-represented or excluded from clinical trials.

The BALKAN-AF survey is the largest prospective, multicenter (a total of 49 centres), observational AF dataset from the Balkans, a European region inhabited by about $10 \%$ of the European population that has been under-represented in many prior clinical trials or registries [1]. In BALKAN-AF, data regarding consecutive subjects with electrocardiographically documented non-valvular AF were collected in seven Balkan countries (Albania, Bosnia \& Herzegovina, Bulgaria, Croatia, Montenegro, Romania and Serbia) by a cardiologist or an internal medicine specialist where cardiologist was not available. The Serbian Atrial Fibrillation Association created and conducted the BALKAN-AF survey (performed from December 2014 to February 2015). 
В една скорошна студия BALKAN-AF [2] е направена цялостна оценка на придържането към подхода ABC (A, Avoid stroke with anticoagulation [Избягване на инсулта чрез антикоагулация]; $B$, Better symptom management with rate or rhythm control [По-добро овладяване на симптоматиката чрез честотен или ритъмен контрол]; С, Cardiovascular and comorbidity risk management [Лечение на сърдечно-съдовия и коморбидния риск]) и идентификкация на основните пропуски в спазването на пътя $\mathrm{ABC}$ сред участниците в обследването BALKAN-AF [3]. В участващите страни от балканския регион придържането към пътеката за интегрирано поведение при AF, обозначена като $\mathrm{ABC}$, е било субоптимално и по-малко от половината пациенти с AF са получили лечение, съответстващо на "A+B+C". Възраст $\geq 80$ години и хеморагична анамнеза са били мултивариантни предиктори за непридържащо се към “A+B+C" лечение, докато грижи в голям град, лечение, проведено от кардиолог, хипертония, захарен диабет (DM) и полиморбидност са били независими предиктори за спазване на "A+B+C" поведение.

Превенцията на инсулта е била оценена при много възрастни пациенти ( $\geq 80$ г.) от балканския регион с невалвуларно AF [4]. При пациенти на възраст $\geq 80$ години честотата на употреба на перорална антикоагулация (ОАС) е била 64\% при по-често използване на аспирин в сравнение с не толкова възрастни лица. Нещо повече, в групата с напреднала възраст рисковете от инсулт и хеморагия не са поставени във връзка с употребата на ОАС, а употребата на OAC e била по-малко вероятна при много възрастни лица с новооткрито AF, по-висок NYHA (New York Heart Association) клас или едновременна антитромбоцитна лекарствена терапия. По-вероятно е било и при много възрастните пациенти да се използва стратегия за контрол на ритъма, а за контрол на честотата обикновено е използван дигоксин.

В по-нататъшно проучване е направена оценка на модела на антитромбозно лечение при пациентите с невалвуларно AF, участвали в проучването BALKAN-AF [5]. Като цяло използването на OAC за превенция на инсулта е с приемлива честота (приблизително 74\%) и подобно на това в други европейски страни, но зависимостта между ОАС и инсултния риск при конкретния пациент (указана в препоръките на Европейското кардиологично дружество (ESC) [6]) е била слаба. Обобщената честота на употреба на OAC сред пациентите от България е $72.0 \%$, NOACs са предписани при $28.9 \%$, а аспирин е използван за инсултна превенция при $12.2 \%$.

За съжаление, качеството на пероралната антикоагулация не е добро, като по-малко от една трета от пациентите са поддържали време в терапевтични граници $\geq 65 \%$. Употребата на антитромбоцитни средства е сравнително висока, подобно на тази
In one recent BALKAN-AF study [2], adherence to the $A B C$ ( $A$, Avoid stroke with anticoagulation; B, Better symptom management with rate or rhythm control; C, Cardiovascular and comorbidity risk management) holistic approach was evaluated and major gaps in adherence to the $A B C$ pathway among participants of the BALKAN-AF survey were identified [3]. In the participating countries in the Balkan region adherence to the $A B C$ pathway for integrated management of AF patients was suboptimal and less than half of AF patients received the " $A+B+C$ "-adherent management. Age $\geq$ 80 years and history of bleeding were multivariable predictors of " $A+B+C$ "-non-adherent management, whilst capital city care, treatment by cardiologist, hypertension, diabetes mellitus (DM) and multimorbidity were independently associated with " $A+B+C$ "-adherent management.

Stroke prevention was assessed in elderly (aged $\geq$ 80) patients with non-valvular AF in the Balkan region [4]. The prevalence of oral anticoagulation (OAC) use in patients aged $\geq 80$ years was $64 \%$ with a higher use of aspirin compared to non-elderly individuals. Moreover, stroke and bleeding risk scores were being not associated with OAC use in the elderly; however, the use of OAC was less likely in elderly patients with newly-diagnosed AF, greater NYHA (New York Heart Association) class or concomitant antiplatelet drug therapy. Elderly patients were also more likely to receive rhythm control strategy, and digoxin was commonly used for rate control.

In a further study, patterns of antithrombotic treatment in patients with non-valvular AF were evaluated in participants of the BALKAN-AF study [5]. The overall use of OAC for stroke prevention was acceptable (approximately $74 \%$ ) and similar to other European countries, but the association of OAC with individual patient stroke risk (recommended by European Society of Cardiology (ESC) guidelines [6]) was poor. Of note, the overall rate of OAC use among patients from Bulgaria was $72.0 \%$, NOACs were prescribed to $28.9 \%$, and aspirin was used for stroke prevention in $12.2 \%$.

Unfortunately, the quality of oral anticoagulation was also poor and less than one third of patients maintained a time in therapeutic range $\geq 65 \%$. Moreover, the use of antiplatelets was comparably high as in other countries in Europe. The prevalence of non-vitamin $\mathrm{K}$ antagonist oral anticoagulants (NOAC) in the Balkan region (approximately $17 \%$ of all patients given $\mathrm{OAC}$ ) 
в други страни от Европа. Честотата на приложение на невитамин К-антагонистични перорални антикоагуланти (NOAC) в балканския регион (приблизително 17\% от всички пациенти, получаващи ОАС) е сравнима с тази в други европейски страни, но не е била зависима от клиничните признаци при пациентите или от индивидуалния инсултен или хеморагичен риск [7]. Употребата на NOAC се е определяла предимно от фактори, различни от базирано на доказателства вземане на решение (в това число реимбурсационна политика, лекарствена наличност на пазара). Както би могло да се очаква, кардиолозите са били по-склонни да предпишат NOACs в сравнение със специалистите по вътрешни болести. Независими предиктори за повишена употреба на NOACs са били злокачествени заболявания, стратегия на кардиолозите за контрол и овладяване на ритъма, докато сърдечната недостатъчност (HF), клапното сърдечно заболяване, предшестващата употреба на ОАС, комбинирането на ОАС с антитромбоцитни средства и лечението в болничен център са в отрицателна връзка с употребата на NOAC.

Докладвани са и лекарствено-специфични модели на употреба на NOACs. При по-млади пациенти, с по-висок креатининов клирънс $(\mathrm{CrCl})$ и по-ниски рискове за инсултни (CHA2DS2-VASc [застойна сърдечна недостатъчност, хипертония, възраст $\geq$ 75 години, DM, инсулт/транзиторна исхемична атака, съдово заболяване, възраст 65 до 74 години, полова принадлежност [6]) и хеморагични рискове (HAS-BLED [хипертония, нарушена бъбречна/чернодробна функция, инсулт, хеморагична анамнеза или предиспозиция, лабилно международно нормализирано отношение (INR), напреднала възраст (> 65 години), съпътстващи лекарства или алкохол) [6]) е имало по-голяма вероятност да получат дабигатран. Лица с по-неблагоприятен рисков профил (т.е. по-стари пациенти, с по-нисък $\mathrm{CrCl}$, по-висок инсултен и хеморагичен риск) са лекувани по-често с ривароксабан или апиксабан [7].

Приблизително един на четири пациенти от изследването BALKAN-AF са били с новодиагностицирано AF. Тези пациенти са били по-млади, с по-малко коморбидност и по-нисък риск от инсулт и хеморагия, но по-симптомни и с по-голяма вероятност за пароксизмално AF от тези с предшестващо известно AF. Представени са и разликите в поведението към AF между пациенти с новоустановено AF и тези с анамнеза за AF. Първите са били хоспитализирани по-често по повод AF, по-рядко са получавали ОАС, но са били третирани по-често с антитромбоцитна монотерапия и стратегия за ритъмен контрол [8].

Какви са следващите стъпки? Проучванията върху популацията на BALKAN-AF подчертават незадоволените нужди, пропуските в познанията и системните бариери, на които трябва да се обърне was comparable to other European countries, but was not associated with patients' clinical features or individual stroke or bleeding risk (7). NOAC use was predominantly guided by factors different than evidence-based decision making (among others, reimbursement policy, drug availability on the market). As could be expected, cardiologists were more likely to prescribe NOACs than internal medicine specialists. Malignancy, rhythm control strategy and management by cardiologist were independent predictors of increased NOACs use, whilst heart failure (HF), valvular heart disease, prior OAC use, combination of OAC with antiplatelets and treatment in hospital-based centre were negatively associated with NOAC use.

Drug-specific patterns of NOACs use were also reported. Younger patients with higher creatinine clearance $(\mathrm{CrCl})$ and lower stroke [CHA2DS2-VASc (congestive heart failure, hypertension, age $\geq 75$ years, DM, stroke/transient ischaemic attack, vascular disease, age 65 to 74 years, sex category) [6]] and bleeding risks [HAS-BLED (hypertension, abnormal renal/liver function, stroke, bleeding history or predisposition, labile International Normalized Ratio (INR), elderly (>65 years), drugs or alcohol concomitantly) [6]] were more likely to receive dabigatran. Individuals with less favorable risk profiles (i.e., older patients, with lower $\mathrm{CrCl}$, higher stroke and bleeding risks) were more often managed with rivaroxaban or apixaban [7].

Approximately one out of four patients in the BALKAN-AF survey had newly-diagnosed AF. Those patients were younger, with less comorbidity and lower stroke and bleeding risk, but more symptomatic and more likely to have paroxysmal AF than those with previously known AF. Differences in the management of $A F$ between patients with newly-diagnosed $A F$ and those with a history of AF were presented. The former were more often hospitalized for $A F$, less often received OAC, but were more often medicated with single antiplatelet therapy alone and rhythm control strategy [8].

What are the next steps? Studies associated with BALKAN-AF population emphasized the unmet needs, knowledge gaps and system barriers that should be addressed to improve the care for AF patients in the Balkan region. For example, paroxysmal $A F$ was associated with decreased compliance with "A-" (A, Avoid stroke with anticoagulation), "B-" (B, Better symptom management with rate or rhythm control) and "A+B"-adherent management [2]. Important- 
внимание с цел подобряване на грижите при пациенти с AF в балканския регион. Например пароксизмалното AF е било свързано с намален комплайънс към "А“ (А, Избягване на инсулта чрез антикоагулация), "В“ (В, По-добро овладяване на симптоматиката чрез честотен или ритъмен контрол) и придържане към “А+B” [2]. Важно е да се знае, че модельт на AF не трябва да влияе на решението за използване на ОАС. Показанията за ОАС при лица с пароксизмално AF трябва да се базират на оценката за инсултните рискови фактори [9].

Коронарната артериална болест (CAD) се оказва маркер за непридържане към терапията с ОАС при пациенти, включени в обследването BALKAN-AF. Ha приблизително 17\% от пациентите с CHA2DS2-VASc, скор $\geq 2$, са предписани само антитромбоцитни средства, което е неоправдано поради повишен хеморагичен риск и липса на редукция на инсулта или смъртността $[10,11]$. Добре е, че приблизително $72 \%$ от пациентите в проучване BALKAN-AF са получавали оптимално медикаментозно лечение за коморбидностите си, а HF, хроничното бъбречно заболяване (CKD) и хеморагичните прояви са били независими предиктори на по-малка вероятност за придържане към “C” (C, Лечение на сърдечно-съдовия и коморбидния риск) [2]. Защо това е важно? Цялостното поведение при AF придоби популярност с цел подобряване на клиничния изход при пациентите. Има доказателства, че придържането към подхода АВС е свързано с по-нисък риск от сърдечно-съдови усложнения и намалява сигнификантно здравните разходи в сравнение с неспазването на АBC подхода [12-14].

В заключение, целите на изследването BALKANAF бяха да се идентифицират субоптимални практически подходи към AF в голям европейски регион и да бъде допълнена европейската „карта“ на поведение при AF в реалния свят. Бяха осигурени и познания, отнасящи се за придържането към препоръките при AF в балканските страни. Резултатите от проучванията изглежда осигуряват насоки за допълнителните усилия, необходими за подобряване на подхода при AF в участвалите балкански страни. Важно е, че спазването на препоръките за поведение на ESC са свързани със сигнификантно по-добър клиничен изход [15]. Трябва да се подчертае, че тези данни върху пациентските характеристики и поведението при AF в този голям европейски регион имат важно значение за клиничната практика в реалния свят. Очакваме подобни големи и добре водени регионални регистри.

\section{Декларация за интереси}

GYH Lip е консултант на Bayer/Janssen, BMS/Pfizer, Medtronic, Boehringer Ingelheim, Novartis, Verseon и Daiichi-Sankyo; също и говорител за Bayer, BMS/Pfizer, Medtronic, Boehringer Ingelheim и Daiichi-Sankyo; не получава преки лични възнаграждения.

Профресор Potpara е и била консултант на Bayer/Jansen и BMS/Pfizer (без възнаграждения). ly, the pattern of AF should not affect the decision to use OAC. Indications to OAC in individuals with paroxysmal AF should be based on assessment of stroke risk factors [9].

Coronary artery disease (CAD) was a marker of guideline non-adherence to OAC therapy in patients enrolled to the BALKAN-AF survey. Approximately $17 \%$ of patients with CHA2DS2-VASc score $\geq 2$ were prescribed antiplatelets alone, which is not justified owing to increased risk of bleeding and lack of reduction of stroke or mortality [10, 11]. Reassuringly, approximately $72 \%$ of patients in the BALKAN-AF study had their comorbidities optimally medicated, and HF, chronic kidney disease (CKD) and bleeding events were independent predictors of lower likelihood of "C"-adherent management ( $\mathrm{C}$, Cardiovascular and comorbidity risk management) [2].

Why is this important? The holistic management of AF has been popularized to improve patients' outcomes. There is evidence that adherence to the $A B C$ pathway has been associated with a lower rate of cardiovascular events and significantly reduced healthcare costs compared with non-compliance with $A B C$ approach [12-14].

In conclusion, the BALKAN-AF survey was designed to identify suboptimal AF management practices in a large region of Europe and to complement the European 'map' of real-world AF management. It has also provided insight into adherence of $A F$ guidelines in the Balkan countries. The results of the studies seem to enable guidance on the additional attempts needed to improve AF management in the participating Balkan countries. Importantly, ESC-guideline adherent management is associated with significantly better outcomes [15]. It should be emphasized that such data addressing patient characteristics and AF management in a large European region are important for the real-world clinical practice. We look forwards to similar large and well conducted regional registries.

\section{Declaration of Interests}

GYH Lip is a consultant for Bayer/Janssen, BMS/Pfizer, Medtronic, Boehringer Ingelheim, Novartis, Verseon, and Daiichi-Sankyo; and a speaker for Bayer, BMS/Pfizer, Medtronic, Boehringer Ingelheim, and Daiichi-Sankyo; no fees are directly received personally.

Professor Potpara has been a consultant for Bayer/Jansen and BMS/Pfizer (no fees). 


\section{Библиография / References}

1. Potpara TS, Lip GY. Patterns in atrial fibrillation management and ,real-world' adherence to guidelines in the Balkan Region: an overview of the Balkan-atrial fibrillation survey. Eur Heart J. 2015;36(30):1943-4.

2. Kozieł M, Simovic S, Pavlovic N et al. Adherence to the ABC (Atrial fibrillation Better Care) Pathway in the Balkan region: The BALKAN-AF Survey. Polish Archives of Internal Medicine [Internet]. 2020.

3. Lip GYH. The ABC pathway: an integrated approach to improve AF management. Nat Rev Cardiol. 2017;14(11):627-8.

4. Potpara TS, Simovic S, Pavlovic $\mathrm{N}$ et al. Stroke prevention in elderly patients with non-valvular atrial fibrillation in the BALKAN-AF survey. Eur J Clin Invest. 2020:e13200.

5. Potpara TS, Dan GA, Trendafilova E et al. Stroke prevention in atrial fibrillation and ,real world' adherence to guidelines in the Balkan Region: The BALKAN-AF Survey. Sci Rep. 2016;6:20432.

6. Kirchhof P, Benussi S, Kotecha Det al. 2016 ESC Guidelines for the management of atrial fibrillation developed in collaboration with EACTS. Eur Heart J. 2016;37(38):2893-962.

7. Potpara TS, Trendafilova E, Dan GA et al. The Patterns of Non-vitamin K Antagonist Oral Anticoagulants (NOACs) Use in Patients with Atrial Fibrillation in Seven Balkan Countries: a Report from the BALKAN-AF Survey. Adv Ther. 2017;34(8):2043-57.

8. Kozieł M, Simovic S, Pavlovic N et al. Management of patients with newly-diagnosed atrial fibrillation: Insights from the BALKAN-AF survey. IJC Heart \& Vasculature [Internet]. 2019.
9. Lip GYH, Banerjee A, Boriani G et al. Antithrombotic Therapy for Atrial Fibrillation: CHEST Guideline and Expert Panel Report. Chest. 2018;154(5):1121-201.

10. Connolly SJ, Pogue J, Hart RG et al. Effect of clopidogrel added to aspirin in patients with atrial fibrillation. $\mathrm{N}$ Engl $\mathrm{J}$ Med. 2009;360(20):2066-78.

11. Lip GY. The role of aspirin for stroke prevention in atrial fibrillation. Nat Rev Cardiol. 8. England 2011. p. 602-6.

12. Proietti M, Romiti GF, Olshansky B et al. Improved Outcomes by Integrated Care of Anticoagulated Patients with Atrial Fibrillation Using the Simple ABC (Atrial Fibrillation Better Care) Pathway. Am J Med. 2018;131(11):1359-66.e6.

13. Pastori D, Farcomeni A, Pignatelli P et al. ABC (Atrial fibrillation Better Care) Pathway and Healthcare Costs in Atrial Fibrillation: The ATHERO-AF Study. Am J Med. 2019.

14. Pastori D, Pignatelli $P$, Menichelli $D$ et al. Integrated Care Management of Patients With Atrial Fibrillation and Risk of Cardiovascular Events: The ABC (Atrial fibrillation Better Care) Pathway in the ATHERO-AF Study Cohort. Mayo Clin Proc. 2019;94(7):1261-7.

15. Lip GYH, Laroche C, Popescu Ml et al. Improved outcomes with European Society of Cardiology guideline-adherent antithrombotic treatment in high-risk patients with atrial fibrillation: a report from the EORP-AF General Pilot Registry. EP Europace. 2015;17(12):1777-86.

Превод на български език: д-р Максим Хазан 